\title{
Growth and Characterization of PbO Nanorods Grown using Facile Oxidation of Lead Sheet
}

(Pertumbuhan dan Pencirian Nanorod PbO Menggunakan Pengoksidaan

Mudah dengan Kepingan Plumbum)

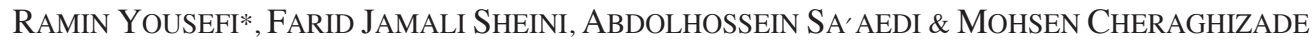

\begin{abstract}
$\mathrm{PbO}$ nanorods were synthesized by oxidation of lead sheets under an oxygen ambiance with different temperatures at $330,400,450$ and $550^{\circ} \mathrm{C}$ in a tube furnace. Scanning electron microscope (SEM) results showed that the nanorods started growing on the sheet that was placed at $330^{\circ} \mathrm{C}$. On the other hand, by increasing of the temperature to $550^{\circ} \mathrm{C}$ more nanorods appeared on the Pb sheet, which were lied on the lead sheet.X-ray diffraction pattern (XRD) indicated that the nanorods had $\alpha-P b O$ structures. However, a few $\beta$-PbO phases also appeared for the nanorods. Raman measurements confirmed the XRD results and indicated two Raman active modes that belonged to $\alpha-P b O$ phase for the nanorods. In addition, the Raman spectrum of the nanorods showed a weak peak of the $\beta$-PbO structure. The optical properties of the products were characterized using a room temperature photoluminescence $(P L)$ technique. The PL result indicated a band gap for the PbO nanorods in the visible region.
\end{abstract}

Keywords: Lead oxide; oxidation; $\mathrm{PbO}$ nanorods; photoluminescence; Raman

ABSTRAK

Nanorod $\mathrm{PbO}$ telah disintesis oleh pengoksidaan kepingan plumbum di bawah suasana oksigen dengan suhu berbeza pada 330, 400, 450 dan $550^{\circ} \mathrm{C}$ di dalam tiub relau. Hasil kajian melalui mikroskop elektron imbasan (SEM) menunjukkan bahawa nanorod mula berkembang atas kepingan yang diletakkan pada $330^{\circ} \mathrm{C}$. Sebaliknya, dengan meningkatkan suhu kepada $550^{\circ} \mathrm{C}$ lebih banyak nanorod muncul di atas kepingan Pb yang telah disusun atas kepingan plumbum. Corak pembelauan sinar-x (XRD) menunjukkan bahawa nanorod mempunyai struktur $\alpha-P b O$. Walau bagaimanapun, beberapa fasa $\beta$-PbO juga muncul bagi nanorod ini. Ukuran Raman mengesahkan keputusan XRD dan menunjukkan dua mod aktif Raman kepunyaan fasa $\alpha-P b O$ bagi nanorod ini. Di samping itu, spektrum nanorod Raman menunjukkan puncak lemah bagi struktur $\beta$-PbO. Sifat optik produk telah dicirikan menggunakan teknik fotoluminesen (PL) pada suhu bilik. Hasil PL menunjukkan jurang jalur untuk nanorod PbO berada di rantau boleh lihat.

Kata kunci: Fotoluminesen; nanorod PbO; pengoksidaan; plumbum oksida; Raman

\section{INTRODUCTION}

Over the past decades, the understanding of semiconductor nanostructures has contributed significantly in the development of nanotechnology. These new developments and applications of semiconductor nanostructures have attracted both the scientific and industrial communities to focus on this class of materials. In semiconductor nanowires and nanobelts, the huge surface to volume ratio $\left(\sim 10^{8} \mathrm{~m}^{-1}\right.$ for nanowires as compared with $\sim 10^{2} \mathrm{~m}^{-1}$ for bulk materials) results in strong sensitivity of the excitons to surface states and as well as defects caused by their reduced size. Therefore, investigation on the electrical and optical properties in one-dimensional (1D) semiconductors is extremely important in order to understand in detail how the electronic states are modified by these types of effects in nearly $1 \mathrm{D}$ structure.

Lead oxide is one of these semiconductors that have important applications in storage batteries, glass industry and pigments (Chen et al. 2011). So far, various forms of $\mathrm{PbO}$ and their compositions nanostructures such as nanoplates and nanostars (Chen et al. 2011), nanorods (Ghasemi et al. 2008), nanopowders (Kashani-Motlagh \& Karami Mahmoudabad 2011) and nanosheets and nanotubes (Shi et al. 2008) have been reported. $\mathrm{PbO}$ is also a semiconductor with a direct band gap energy $(\sim 1.9 \mathrm{eV})$. Recently, several new routes have been used to synthesize $\mathrm{PbO}$ nanostructures, such as calcinations (Li et al. 2012), sonochemical methods (Soltanian Fard et al. 2013), combustion of gel (Karami Mahmoudabad \& KashaniMotlagh 2011), anodic oxidation (Singh \& Srivastava 2011), hydrothermal method (Jia \& Gao et al. 2006) and thermal decomposition (Behnoudnia \& Dehghani 2012). Most of these techniques are complex, expensive and time consuming. In addition, the final products of these methods have not shown a good crystalline quality.

Among all sintering methods, the direct thermal oxidation of a high purity metal sheet is a cost effective and the simplest method. In addition, it has a great potential 
to be adopted for large-scale production of metal oxide nanostructures. Recently, this method has been used to grow $\mathrm{CuO}$ nanowires (Farbod et al. 2012). We also reported this method to grow $\mathrm{ZnO}$ nanowires (Jamali-Sheini et al. 2012). Therefore, this method has been used to grow lead oxide nanorods in this research. In this work, a simple oxidation of lead sheets in a horizontal tube furnace in an oxygen ambiance was carried out to synthesize $\mathrm{PbO}$ nanorods. In addition, optical characterizations indicated a good quality for the obtained products from this method.

\section{EXPERIMENTAL DETAILS}

The $\mathrm{PbO}$ nanorods were grown by a CVD set-up in a tube furnace. Firstly, two high purity $\mathrm{Pb}$ sheets (99.99\%), with dimensions of $1 \times 1 \mathrm{~cm}$ and a thickness of $0.5 \mathrm{~mm}$ were used as substrates and source materials. The sheets were ultrasonically cleaned in acetone and methanol for $10 \mathrm{~min}$ in each solvent. The furnace heated up to $600^{\circ} \mathrm{C}$ and the lead sheets temperatures were varied between 330 and $550^{\circ} \mathrm{C}$. A mixture of high purity $\mathrm{N}_{2} / \mathrm{O}_{2}, 10: 2$ gases was fed at about $100 \mathrm{sccm}$ into the furnace at one end, while the other end was connected to a rotary pump. The growth process was allowed to proceed for $2 \mathrm{~h}$. A vacuum of 6 Torr was maintained inside the tube furnace during oxidation of the $\mathrm{Pb}$ sheet.

The morphology and crystal structure of the products were investigated using a field emission scanning electron microscope (SEM, Hitachi S4160) and an X-ray diffractometer (XRD, Phillips PW3040/60). Room temperature photoluminescence (Perklin Elmer LS55) and Raman (Almega Thermo Nicolet Dispersive Raman Spectrometer) spectrometers were employed to study the optical properties and crystallinity of the $\mathrm{PbO}$ nanostructures, respectively. A Xenon arc lamp as the light source was used for the PL and an Nd: YLF laser with a wavelength of $532 \mathrm{~nm}$ were used for Raman measurements.

\section{RESULTS AND DISCUSSION}

Figure 1 shows the SEM images of the sheets that have been placed at different temperatures. It can be seen that nanorods started growing on the sheet that has been placed at $330^{\circ} \mathrm{C}$ (Figure 1(a) and $1(\mathrm{~b})$ ). It cannot be seen on any different morphologies at 400 and $450^{\circ} \mathrm{C}$. On the other hand, the formation of nanorods improves when the oxidation temperature increases to $550^{\circ} \mathrm{C}$ (Figure 1(c) and $1(\mathrm{~d})$ ). However, it was seen as deformation in lead sheet at $550^{\circ} \mathrm{C}$. In addition, the SEM images showed that the nanorods lied on the $\mathrm{Pb}$ sheet and the average diameter of the nanorods is around $90 \mathrm{~nm}$.

Figure 2 shows the XRD patterns of the sheets, which have been placed at 330 and $550^{\circ} \mathrm{C}$. It can be seen, the XRD pattern of the sheet, which has been placed at $330^{\circ} \mathrm{C}$, indicates two phases, one $\mathrm{Pb}$ phase and another $\alpha-\mathrm{PbO}$ phase with tetragonal structure (JCDPDS Card No.50561). In addition, Figure 2 indicates the XRD pattern of the sheet that has been placed at $550^{\circ} \mathrm{C}$. It can be observed that the phase of the sample in this temperature is $\alpha-\mathrm{PbO}$, completely and $\mathrm{Pb}$ phase has disappeared. However, a small amount of $\beta$-PbO also appear in this sample. Therefore, the nanorods can be $\alpha-\mathrm{PbO}$.

Raman spectroscopy is an effective technique for estimating the crystallinity of materials. According to the group theory, single crystalline $\alpha$-PbO belongs to the $\mathrm{D}^{7}$ space group having two formula units per primitive cell. The factor-group analysis as well as the site symmetry analysis gives the representation $\Gamma_{\text {opt }}$ for the optical vibration modes of $\alpha-\mathrm{PbO}$,

$$
\Gamma_{\mathrm{opt}}=\mathrm{A}_{1 \mathrm{~g}}+\mathrm{B}_{1 \mathrm{~g}}+2 \mathrm{E}_{\mathrm{g}}+\mathrm{A}_{2 \mathrm{u}}+\mathrm{E}_{\mathrm{u}},
$$

where $\mathrm{A}_{1 \mathrm{~g}}, \mathrm{~B}_{1 \mathrm{~g}}$ and $\mathrm{E}_{\mathrm{g}}$ are Raman active modes and $\mathrm{A}_{2 \mathrm{u}}$ and $\mathrm{E}_{\mathrm{u}}$ are infrared active modes (Baleva \& Tuncheva 1994; Wiechert et al. 2005). Figure 3 shows the Raman spectra

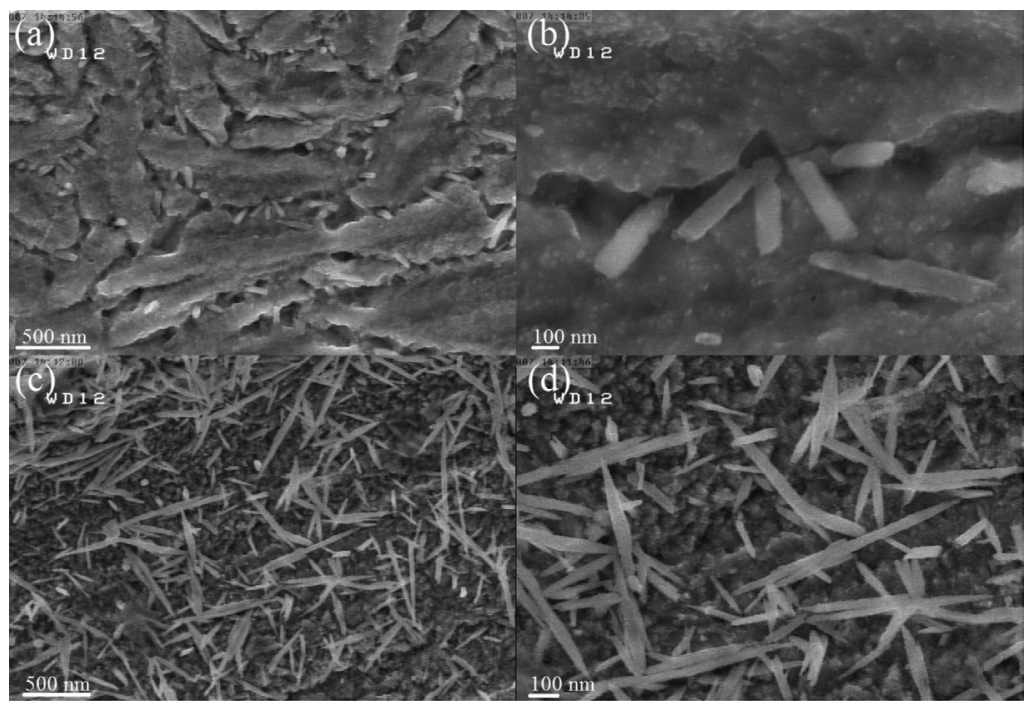

FIGURE 1. SEM images of the nanorods that form at different temperatures of the lead sheets with different magnifications (a-b) $330^{\circ} \mathrm{C}$ and (c-d) $550^{\circ} \mathrm{C}$ 


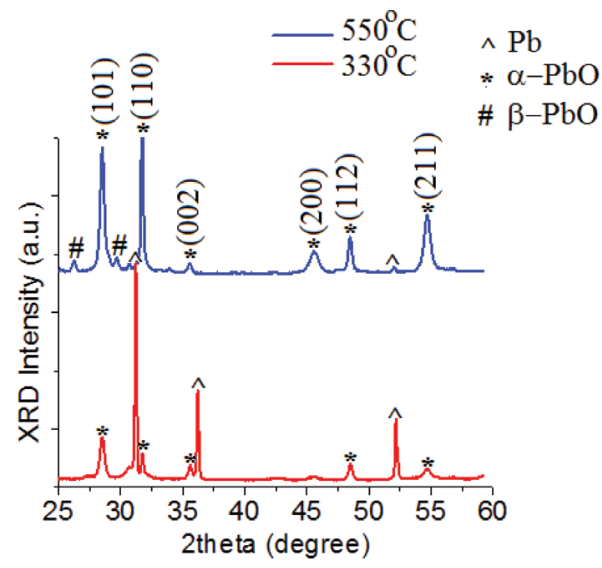

FIGURE 2. XRD pattern of the lead sheets that have been placed at different temperatures

of the nanorods. The Raman spectrum of the nanorods is exactly match with the $\alpha-\mathrm{PbO}$ structure that was reported previously (Baleva \& Tuncheva 1994; Wiechert et al. 2005). As shown in Figure 3, the Raman spectrum of the $\mathrm{PbO}$ nanorods show a sharp, strong and dominant peak at $140 \mathrm{~cm}^{-1}$ corresponding to the $\mathrm{A}_{\mathrm{lg}}$ mode of the Raman active mode, a characteristic peak for the motion of the lead atoms parallel to the c-axis. On the other hand, a peak that appears at $341 \mathrm{~cm}^{-1}$ corresponding to the $\mathrm{B}_{1 \mathrm{~g}}$ mode of the Raman active, a characteristic peak for the motion of the lighter oxygen atoms parallel to the c-axis. In fact, these peaks indicated a high crystal quality for the obtained products. In addition, the Raman spectrum of the nanorods shows an addition weak peak at $233 \mathrm{~cm}^{-1}$ that belongs to $\beta$ - $\mathrm{PbO}$ structure. In fact, the Raman results are in good agreement with the XRD results.

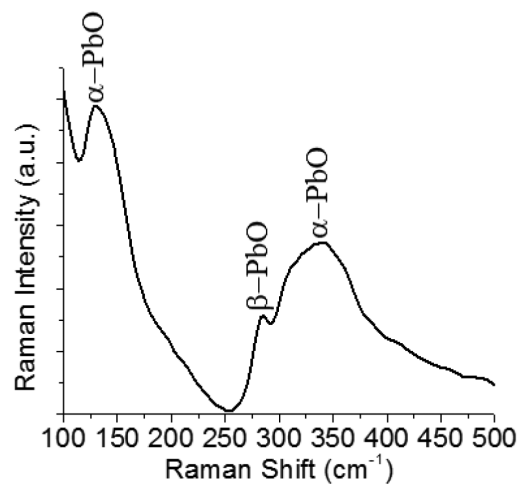

FIGURE 3. Raman spectrum of the $\mathrm{PbO}$ nanorods that were grown at $550^{\circ} \mathrm{C}$

According to obtained results, the formation of different phase of $\mathrm{PbO}$ can be tentatively proposed.

$$
\begin{aligned}
& 2 \mathrm{~Pb} \text { (sheet) }+\mathrm{O}_{2} \text { (gas) } \Rightarrow 2 \alpha-\mathrm{PbO} \text { (nanorods start grow) } \\
& \stackrel{\text { T⿱ }}{\Rightarrow} 2 \alpha-\mathrm{PbO} \text { (nanorods) }+2 \beta-\mathrm{PbO} .
\end{aligned}
$$

In order to investigate the ability of lead oxide nanorods in optoelectronic applications, optical properties were also studied by a room temperature photoluminescence (PL) spectroscopy. Figure 4 shows the PL spectrum of the $\mathrm{PbO}$ nanorods. The PL spectrum showed a broad peak in the visible region at $651 \mathrm{~nm}(1.9 \mathrm{eV})$ for the $\mathrm{PbO}$ nanorods. The value $1.9 \mathrm{eV}$ is in good agreement with the reported band gap values of $\alpha-\mathrm{PbO}$ (Veluchamy \& Minoura 1995) The visible band emission is attributed to the band-edge excitation recombination of $\mathrm{PbO}$. It is expected that, because of the presence of a band gap in the visible region, there is a possibility of using the obtained products as a photovoltaic unit.

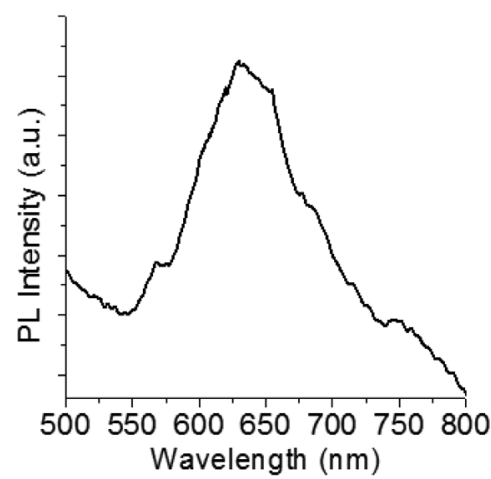

FIGURE 4. PL spectrum of the $\mathrm{PbO}$ nanorods that were grown at $550^{\circ} \mathrm{C}$

\section{CONCLUSION}

The oxidation of lead sheets in the different temperatures was used to grow $\mathrm{PbO}$ nanorods. The SEM showed nanorods started growing on the lead sheets that were placed at $330^{\circ} \mathrm{C}$, while more $\mathrm{PbO}$ nanorods appeared on the sheet that placed at $550^{\circ} \mathrm{C}$. The XRD patterns showed that, $\alpha-\mathrm{PbO}$ phase started to form at $330^{\circ} \mathrm{C}$ and completed at $550^{\circ} \mathrm{C}$. However, a small amount of $\beta-\mathrm{PbO}$ phase was also formed at $550^{\circ} \mathrm{C}$. The Raman measurements indicated two Raman active modes that belonged to $\alpha-\mathrm{PbO}$ phase for the nanorods. The PL results showed that, the band gap of the $\alpha-\mathrm{PbO}$ nanorods was $1.9 \mathrm{eV}$. Such simple method can be used to grow the other metal oxide nanostructures in the future.

\section{ACKNOWLEDGEMENTS}

R. Yousefi and F. Jamali Sheini gratefully acknowledge the Islamic Azad University (I.A.U), Masjed-Soleiman and Ahwaz Branches, respectively, for their financial support in this research work.

\section{REFERENCES}

Baleva, M.\& Tuncheva, V. 1994. Optical characterization of lead monoxide films grown by laser-assisted deposition. J. Solid State Chem. 110(1): 36-42. 
Behnoudnia, F. \& Dehghani, H. 2012. Synthesis and characterization of novel three-dimensional-cauliflowerlike nanostructure of lead (II) oxalate and its thermal decomposition for preparation of $\mathrm{PbO}$. Inorg. Chem. Commun. 24: 32-39.

Chen, K.C., Wang, C.W., Lee, Y.I. \& Liu, H.G. 2011. Nanoplates and nanostars of $\beta-\mathrm{PbO}$ formed at the air/water interface. Colloids Surf. A. 373(1-3): 124-129.

Farbod, M., Meamar Ghaffari, N. \& Kazeminezhad, I. 2012. Effect of growth parameters on photocatalytic properties of $\mathrm{CuO}$ nanowires fabricated by direct oxidation. Mater. Lett. 81: 258-260.

Ghasemi, S., Mousavi, M.F., Shamsipur, M. \& Karami, H. 2008. Sonochemical-assisted synthesis of nano-structured lead dioxide. Ultrason. Sonochem. 15(4): 448-455.

Jamali-Sheini, F., Yousefi, R. \& Patil, K.R. 2012. Surface characterization of $\mathrm{Au}-\mathrm{ZnO}$ nanowire films. Ceram. Int. 38(8): 6665-6670.

Jia, B. \& Gao, L. 2006. Synthesis and characterization of single crystalline $\mathrm{PbO}$ nanorods via a facile hydrothermal method. Mater. Chem. Phys. 100(2-3): 351-354.

Karami Mahmoudabad, M. \& Kashani-Motlagh, M.M. 2011. Synthesis and characterization of $\mathrm{PbO}$ nanostructure and $\mathrm{NiO}$ doped with $\mathrm{PbO}$ through combustion of citrate/nitrate gel. International Journal of the Physical Sciences 6(24): 5720-5725.

Kashani-Motlagh, M.M. \& Karami Mahmoudabad, M. 2011 Synthesis and characterization of lead oxide nano-powders by sol-gel method. J. Sol-Gel Sci. Technol. 59: 106-110.

Li, L., Zhu, X., Yang, D., Gao, L., Liu, J., Kumar, R.V. \& Yang, J. 2012. Preparation and characterization of nano-structured lead oxide from spent lead acid battery paste. Journal of Hazardous Materials. 203-204: 274-282.

Shi, L., Xu, Y. \& Li, Q. 2008. Controlled growth of lead oxide nanosheets, scrolled nanotubes, and nanorods. Crystal Growth \& Design 8(10): 3521-3525.

Singh, D.P. \& Srivastava, O.N. 2011. Synthesis of micron-sized hexagonal and flowerlike nanostructures of lead oxide $\left(\mathrm{PbO}_{2}\right)$ by anodic oxidation of lead. Nano-Micro Letters 3(4): 223-227.
Soltanian Fard, M.J., Rastaghi, F. \& Ghanbari, N. 2013. Sonochemical synthesis of new nano-two-dimensional lead (II) coordination polymer: As precursor for preparation of $\mathrm{PbO}$ nano-structure. J. Mol. Struct. 1032: 133-137.

Veluchamy, P. \& Minoura, H. 1995. Selective formation of $\beta-\mathrm{PbO}$ and $\alpha-\mathrm{PbO}$ films on $\mathrm{Pb}$ electrodes by potentiostatic anodization in alkaline solutions. J. Electroanal. Chem. 396: 211-217.

Wiechert, D.U., Grabowski, S.P. \& Simon, M. 2005. Raman spectroscopic investigation of evaporated $\mathrm{PbO}$ layers. Thin Solid Films 484: 73-82.

Ramin Yousefi*

Depertment of Physics, Masjed-Soleiman Branch

Islamic Azad University (I.A.U)

Masjed-Soleiman

Iran

Farid Jamali Sheini

Department of Physics, Ahwaz Branch

Islamic Azad University, Ahwaz

Iran

Abdolhossein Sa' aedi \& Mohsen Cheraghizade

Department of Electrical Engineering

Bushehr Branch, Islamic Azad University (I.A.U)

Bushehr

Iran

*Corresponding author; email: Yousefi.ramin@gmail.com

Received: 12 June 2013

Accepted: 30 July 2014 